\title{
An Investigation Into Reasons Influencing Kingdom of Saudi Arabian Parents' Choice of Selecting School Related to Quality of Instruction, Class Size, and Student-Teacher Relationships
}

\begin{abstract}
Faisal Alsauidi
University of Hull, Hull, UK

There are various studies, primarily conducted in the Western world, that have investigated the reasons why parents select a school, which they perceive best meets their children's needs, and parental aspirations for their children. In order to contribute to the established knowledge, it was essential to conduct an investigation into parents' reasons for their selection of private or public school in the Kingdom of Saudi Arabia (KSA). Such an investigation had not been conducted previously. This article identified an academic factor highly regarded as influencing parental decision-making, which can be divided into three identified elements, i.e., class size, quality of instruction, and student-teacher relationships. Analysis and discussion along with the study's conclusions and recommendations will be cited. Randomly selected parents, whose children attend private or public schools in Riyadh City, KSA, were invited to complete a standardized questionnaire after which to participate in a semi-structured interview to identify factors that influenced their preference for school. Two methodologies analysis of the reasons given highlighted demonstrating the frequency of the cited range of reasons: class size, quality of instruction, and student-teacher relationships, identified as the main elements that influenced their selection decision-making.
\end{abstract}

Keywords: Saudi Arabian parents' perceptions, class size, quality of instruction, student-teacher relationships

\section{Introduction}

To set this study, in the context of past studies, when selecting an appropriate school, the vast majority of parents prioritize academic quality in their choice of school as they believe their children will receive a better education (Bauch \& Goldring, 1995).

Consequently, data demonstrate that academic quality is at the top or close to the top of the priorities parents cite as important when evaluating whether a school is suitable for their children, because high quality education was perceived as encouraging learners to do their best work and to have high expectations of increasing personal attainment. How this is achieved was perceived primarily through class size, quality of instruction, and student-teacher relationships. Recent researchers found that parents set considerable store by these attributes when choosing a school for their child, e.g., Burgess, McConnell, Propper, and Wilson (2007) found that "parents, almost universally in our data, have a strong preference for schools with high academic attainment" (p. 33).

Faisal Alsauidi, Ph.D., School of Education, University of Hull. 


\section{Literature Review}

\section{Class Size}

Based upon the following discussion, it can be concluded that class size is a very important element in parental considerations when deciding upon which private or public school to choose. Furthermore, such parental decisions are based on the assumption that a smaller class equates to a more suitable and better quality learning environment in which the student's achievements and development will be enhanced through a constructive relationship between teachers and learners in which teachers have more time to devote to supporting each individual learner.

There are various definitions of class size. For instance, according to Scheck, Kinicki, and Webster (1994), a small class can contain as many as 38 learners, while Gibbs, Lucas, and Simonite (1996) defined a class as "small" if it contains no more than 30 pupils and "large" if it contains more than 70 students. In contrast, Nye, Hedges, and Konstantopoulos (2000) defined a class as small if it contains 8-15 pupils.

Whereas, some studies, such as Finn and Achilles (1990), Krueger (1999), and Nye et al. (2000), considered small classes to be on average a size of 15 , and described these as being much more effective and with more positive learning outcomes for students than regular classes, i.e., those with 22 students on average. It can be seen that one of the challenges facing research on class size is the lack of a consistent definition of small and large classes, and this can make it difficult to compare the results of different studies.

Considering the differences between public and private schools in terms of attitudes to class size is also instructive. In the Kingdom of Saudi Arabia (KSA) context, meanwhile, private school enrolment was found to be on average 20 students per class, whereas the public school class size was 45 students on average, resulting in teachers spending a longer time having to exercise discipline as each class size increased (Ministry of Education, 2013).

Notwithstanding the inconclusive research findings discussed above, there are significant numbers of studies, however, that demonstrate that parents base their preference for a specific school upon class size. For instance, small class size was identified by Al-Ansari (2004) in his research survey of 214 parents who already sent their children to private school in Dammam City, KSA. Whilst exploring the reasons influencing parents to prefer private schools over public schools, Al-Ansari (2004) showed that $75 \%$ of parents preferred the private school primarily because of the smaller classes, on account of a perception that:

Small class sizes assist teachers to take account of the different abilities of students, because it makes it easier to use modern strategies of teaching according to the abilities of students. As a result, it increases the students' educational attainment as the students are interesting to raise their skills in the classroom. (p. 9)

Al-Jaji (2002) indicated that in KSA, parents consider class size as a powerful reason behind their choice of school. Despite the fact that the KSA government provides free education for all its citizens, including all textbooks, relevant teaching materials, and equipment, nevertheless, parents in his study still preferred to pay for private education, citing overcrowded classes in public school as the main reason.

Similarly, Al-Mutawa and Al-Watfa (2007) surveyed 674 parents in Kuwait and found that the extent of overcrowding in public school classes was an important primary factor in parental decision-making. Bukari and Randall's (2009, p. 259) research into parents' decision to switch their children from public to private schools in the State of Utah, United States (U.S.), came to similar conclusions that the main reason that influenced 
parental decision-making was class size: "Parents were dismayed by the large class sizes ... in the public schools." It was found that the quality of teaching and class size were the most important qualities parents linked based on the assumption that small class sizes result in enhanced quality of teaching.

In summary, the impact of class size is a controversial issue in that there is no clear consensus among scholars as to whether class size has any real impact on student academic performance. In terms of parental school choice, however, it is clear that (notwithstanding the mixed research picture) parents are convinced that smaller classes lead to better academic results, and therefore, that class size is a significant determinant of school choice.

\section{Quality of Instruction}

A very brief detail of the review of literature supports Angeloni (2012) who concluded that parents rank the quality of instruction - academic and innovative teaching — very highly when choosing a school. While Collins and Snell (2000) indicated that $64 \%$ of parents in the United Kingdom choose a school on the basis of the school's good examination results, making this the most important factor in school choice.

Similarly, Denessena, Driessenaa, and Sleegers (2005) supported the contention that "choosers may also select a school for its high quality of education, high standards of academic achievement" (p. 352). Whilst, Charles (2011) found that the quality of education, along with the geographical proximity of the school, was an important reason for the selection of a particular school.

Specifically, in relation to the importance of academic programmes related to student achievement, a lot of research into the distinctions between public and private schools in terms of student attainment has shown that a high quality academic programme leads to high student achievement. For instance, Bosetti (2004) claimed that the academic element contributed to a successful academic outcome of students. Coleman, Hoffer, and Kilgore (1982) suggested that the reasons were:

First, private schools create higher rates of engagement in academic activities, school attendance is better, students do more homework, and students generally take more rigorous subjects. Second, students' behaviour in school has strong consistent effects on students' achievement. (p. 178)

Nevertheless, this study has been criticized by Anderson and Resnick (1997) as it did not include some of the key variables that distinguish private schools and public schools, such as the type of academic courses they offer. Later studies have attempted to factor a range of other variables into the comparison. For example, the National Center for Education Statistics (NCES) (2003) report examined differences between public and private schools by comparing mean National Assessment of Educational Progress (NAEP) reading and mathematics scores, taking into account selected characteristics of students and/or schools, with a sample of over 6,900 public schools and over 530 private schools. The NCES results showed that Grade 4 and Grade 8 students attending private schools reached a higher level than public school learners. In emerging nations, meanwhile, the consensus in studies into the effectiveness of public $v s$. private schools is that the performance of children in private schools is better that of their counterparts in public schools.

In the KSA context, Al-Ghamdi and Asiri (1992) carried out a study in Taif City to compare public and private schools in terms of the educational attainment of their students. They found that, generally, the private school students were more proficient than the public school students, attributing this mainly to the private school teachers being better qualified than their counterparts in public schools. The sample in this study was very small—only two private schools and two public schools. 
On the other hand, proponents of public schools argue that private schools choose students who only meet academic standards that are higher than public school criteria (Shanker, 1993), and Marlow (2010) supports the argument that the reason for Californian private school students achieving higher marks in tests is that "public school test scores are inversely related to private enrolments, thus supporting the view that private school enrolments partly reflect exiting from public schools due to poor academic performance" (p. 11). In addition, these studies indicated some of the elements that contribute to the academic success of private schools, i.e., suitable educational environment (class size), quality of instruction with attention given to the aspirations of students, a focus on improving students' skills, school attendance, students doing more homework, and schools' emphasis on a good relationship between students and teachers.

\section{Student-Teacher Relationships and Quality of Instruction}

Pianta (1999) defined student-teacher relationships as "emotions-based experiences that emerge out of teachers' on-going interactions with their students" (p. 62).

Good teaching is charged with positive emotion ... Good teachers are not just well-oiled machines. They are emotional, passionate beings who connect with their students and fill their work and classes with pleasure, creativity, challenge and joy. (Hargreaves, 1994, p. 835)

Kyriacou (2007, p. 74) meanwhile emphasized the importance of the relationship between students and teachers in terms of creating an educational climate in the classroom, i.e., quality of instruction.

A positive classroom climate very much depends on the type of relationship you establish with your pupils. Pupils' learning is most likely to flourish in a climate where this relationship is based on mutual respect and rapport between yourself and your pupils.

Kyriacou (2007) also indicated some elements that help to develop a rapport between teachers and students, such as mutual respect and rapport, the use of humor, and enhancing pupils' self-esteem. Some researchers, however, such as Richmond and Gorham (1996), considered that teachers must promote positive relationships with students, because learners look to educators for more than knowledge. Students need to succeed within their classroom, as well as in everyday life. They, therefore, want teachers to help them feel good about themselves by building their self-esteem, and to feel secure and in control of their environment. This is because there is a strong link between student-teacher relationships and quality of instruction being effective. Hence, Burleson and Samter (1990) invited teachers to identify some positive attributes that characterized the development of a relationship with students, for instance, “... calling students by their first name, asking students about themselves, and asking for students' opinions. Non-verbal immediacy consists of behaviours, such as smiling at students, making eye contact, moving about the classroom, and using vocal variety" (p. 10). In addition, Good and Brophy (1995) identified further attributes of the teacher that can enhance strong student-teacher relationships as likability, consideration, positivity, and patience. They postulated that these attributes may promote students' academic performance through quality of instruction provided in a positive climate of support and emotional freedom where students feel confident and not threatened. Thus, according to Knoell (2012), “The teachers' dedication to students' growth helped inspire students to meet the school's requirements, both academic and behavioural, supported by quality of instruction" (p. 10).

The above suggests that the relationship between students and teachers and quality of instruction are very important in assisting students to overcome the educational challenges that they may face in their school lives, e.g., stress, self-esteem, and difficulty in understanding some topics in a variety of lessons. This led Lee (2007) 
to conclude "A trust relationship has been found to function as a motivational resource when students are faced with difficulties in school because trust relationships help adolescents develop positive psychological and emotional perceptions of themselves" (p. 210).

Supporting this, Sauter (1994) found that there were a considerable number of parents who believed that a positive relationship between teachers and students can affect their children's academic performance primarily through encouraging positive motivation implement by quality instruction. Thus, parents valued private schools based their perceived good relationship between teachers and students. Sauter (1994, p. 148) highlighted that "competent and superior teaching staff" is parents' preferred option, after selecting a good education system that implements high standards of quality tuition.

Buttrum (1994) also found, from results obtained from a range of schools, that a positive relationship between teachers and students had very significant effects upon the students and their achievements and their parents' attitude towards the school. Again, this had to be support with quality teaching as the importance of the relationship in terms of school choice was also considered to be one of the primary considerations of parents. So, Cheng (1994, p. 59) found that the manner and attitude of school staff was "strongly related to social climate and student-affective performance leadership styles on use of power, social climate and perceived physical environment, and student affective performance," indicating that good leadership and quality of instruction by teachers were very important for effective learning. In KSA, Albiker (1994) found that parents prefer private schools since they are characterized by positive relationships between teachers and students; they believe that a trust relationship between the teachers and learners/students improved the positive motivation to achieve their best through quality teaching, hence promoting their confidence and respect for self and others.

Similarly, when Charles (2011) surveyed 336 U.S. parents in Tennessee State whilst researching into the comparison between public and private school in terms of the quality of their instruction programme, student-teacher relationships were judged very highly as very important by parents, again establishing the measurable link between these factors.

The above very brief discussion has shown that there is a considerable body of scholarly evidence to suggest that student-teacher relationships and quality of instruction are important influences on students' academic performance and behaviour. Hence, Sauter (1994) highlighted it as an important reason: "Competent and superior teaching staff who implemented strong student-teacher relationships" (p. 148). Meanwhile, the above and following indicates how perception of student-teacher relationships and quality of instruction feeds through to influence parental school choice. For instance, Cheng (1994) found that the ethos of school staff and the way they encouraged sound student-teacher relationships are "strongly related to social climate and student-affective performance" (p. 54).

In KSA, Al-Shimri (1999) surveyed 1,043 parents and determined that the reason that influenced $81 \%$ of these parents to prefer private schools was the strong positive relationship between teachers and students (particularly where teachers encouraged students to express their points of view, and dealt with students equally and fairly) and the quality of teaching offered.

In conclusion, therefore, the beneficial aspects embedded in solid student-teacher relationships linked closely to the quality of instruction implemented are fundamental to school choice, especially when they nurture self-esteem, positive behavioural outcomes, and self-confidence and uphold the existing family standards of behaviour, making the school very attractive to parents. 


\section{Method}

\section{Research Questions}

Two research questions guided this study. The first research question is: Does the strength of the academic factor affect parents' decisions to enter their children into public or private school in Riyadh, KSA?

This question is followed by some supplementary questions identifying the academic factors that may have influenced parents' decisions to enroll their children in public or private school:

1. Does the class size factor affect parents' decisions to enter their children into public or private school in Riyadh, KSA?

2. Does the quality of the instruction factor affect parents' decisions to enter their children into public or private school in Riyadh, KSA?

3. Does the student-teacher relationships factor affect parents' decisions to enter their children into public or private school in Riyadh, KSA?

The second main question is: Why do parents select particular private or public school for academic factor?

\section{Research Design}

A descriptive approach to research has been taken to describe the parents' perception of public and private schools in Riyadh, the capital city of KSA. A descriptive research approach can be broken down into two categories: (a) survey study; and (b) correlational research (Alassaf, 2010).

A survey design was judged to be the most appropriate for the present study for a number of reasons. According to Wisker (2007) and Gilbert (2008), survey studies allow researchers to obtain information about the case, facts, activities, phenomena, moral, personal experiences, behavior, and answers to events. Questionnaires also offer the advantage of allowing sufficient time for the respondents to reflect on their answers. The questionnaire was sent to a large sample at the same time assists researchers in generating data, as the amount and variety of data that can be gathered through a questionnaire are greater than that which can be obtained by other instruments, such as interviews or observations (Wimmer \& Dominick, 2000). Moreover, the researcher is able to obtain data about the sample using several approaches, such as face-to-face interviews, telephone interviews, postal or hand-delivered questionnaires, and online surveys. Cohen, Manion, Morrison, and Bell (2011) confirmed that obtaining data typically involve "structured or semi-structured interviews, self-completion or postal questionnaires, standardized tests of attainment or performance, and attitude scales" (p. 421). Finally, using a survey study is commonly used in educational studies to describe what exists without asking about the reasons. It is "the most commonly used descriptive method in educational research" (Cohen et al., 2011, p. 256). In this study, two methods were used to collect data-questionnaires and focus group interview instrument - which offer an understanding of why parents choose private or public school for their children. Also, focus groups were used in the expectation that they would enrich the validity of the questionnaire by developing an understanding of factors that attract parents to make a particular school choice. Kitzinger (1995) supported this sentiment when he stated that "focus group discussion of a questionnaire is ideal for testing the phrasing of questions and is also useful in explaining or exploring survey results" (p. 300).

\section{Data Collection}

In this study, 15 schools (eight private and seven public schools) were randomly selected by choosing schools from each list, starting from the number 10, then selecting number 20 , then 30 , and so forth. These represent approximately $9 \%$ of both types of school in Riyadh (see Table 1). 
Table 1

Random Selection of Schools

\begin{tabular}{lcc}
\hline Type of school & Total & Sample \\
\hline Public school & 76 & 7 \\
Private school & 87 & 8 \\
Private and public schools & 163 & 15 \\
\hline
\end{tabular}

The student population from the selected eight private schools and seven public schools was a total of 6,554. Lists of parents were obtained through the head teachers in both types of school, being representative of the various groups of parents. For each list, the first or second name was chosen as the starting point, followed by every tenth name after that to form the research sample. If a sibling or a non-Saudi student appeared in the selection process, the next name on the list was taken instead, with the count recommencing from that point.

Table 2 and Table 3 show the number of questionnaires distributed and returned for public schools and private schools during the course of the investigation.

Table 2

Return Rates for Public School Parental Questionnaires

\begin{tabular}{lccl}
\hline Name of school & Surveys sent & Surveys returned & Response rate (\%) \\
\hline School A & 52 & 50 & 96.15 \\
School B & 50 & 30 & 60 \\
School C & 40 & 21 & 52.5 \\
School D & 34 & 20 & 58.8 \\
School E & 30 & 25 & 83.3 \\
School F & 54 & 31 & 57.4 \\
School G & 43 & 17 & 39.4 \\
\hline Total & 303 & 194 & 64 \\
\hline
\end{tabular}

Table 3

Return Rates for Private School Parental Questionnaires

\begin{tabular}{lccl}
\hline Name of school & Surveys sent & Surveys returned & Response rate (\%) \\
\hline School A & 40 & 24 & 60 \\
School B & 42 & 24 & 57.4 \\
School C & 32 & 22 & 69 \\
School D & 44 & 23 & 52.2 \\
School E & 30 & 29 & 96.6 \\
School F & 47 & 24 & 51 \\
School G & 43 & 26 & 60.4 \\
School L & 44 & 20 & 45.4 \\
\hline Total & 322 & 192 & 60 \\
\hline
\end{tabular}

The study was confined to private and public schools and did not include international schools or private and public schools outside the boundaries of Riyadh City.

\section{Analysis and Discussion of Findings}

\section{Class Size}

This section records participants' answers to the sub-question: Does the class size factor affect parents' decisions to enter their children into public or private school in Riyadh, KSA? 
The following details in Table 4 relate to the second of the academic related dimensions: participants' responses to items that were designed to discover their perceptions about the importance of class size in terms of school choice.

Table 4

Frequency, Percent, Mean, and Standard Deviation for Each Item Related to the Class Size Factor

\begin{tabular}{|c|c|c|c|c|c|c|}
\hline \multirow{2}{*}{ Factor } & \multicolumn{3}{|c|}{ Public } & \multicolumn{3}{|c|}{ Private } \\
\hline & $M$ & $S D$ & Rank & $\bar{M}$ & $S D$ & Rank \\
\hline 1. Class size at our school is appropriate for effective learning. & 3.53 & 1.222 & 1 & 4.18 & 0.864 & 1 \\
\hline 2. Student numbers in classrooms are ideal. & 3.02 & 1.267 & 2 & 3.91 & 1.042 & 2 \\
\hline
\end{tabular}

For participants who sent their children to public school, the most important of the class size issues was Item 1, "Class size at our school is appropriate for effective learning," which was rated at 3.53 with a standard deviation of 1.222. This was followed by Item 2, "Student numbers in classrooms are ideal," which was rated at 3.02 with a standard deviation of 1.267 .

Regarding parents who sent their children to private school, the most important class size item was again Item 1; this was rated at 4.18 with a standard deviation of 0.864 . Item 2, meanwhile, was rated at 3.91 with a standard deviation of 1.042 .

\section{Quality of Instruction}

This section records participants' answers to the sub-question: Does the quality of instruction factor affect parents' decisions to enter their children into public or private school in Riyadh, KSA?

The following details in Table 5 offer a record of participants' ratings of their perceptions about the quality of instruction in terms of choosing school, and is followed by a detailed comparison of the responses received.

Table 5

Frequency, Percent, Mean, and Standard Deviation for Each Item Related to the Quality of Instruction Factor

\begin{tabular}{|c|c|c|c|c|c|c|}
\hline \multirow{2}{*}{ Factor } & \multicolumn{3}{|c|}{ Public } & \multicolumn{3}{|c|}{ Private } \\
\hline & $\bar{M}$ & $S D$ & Rank & $M$ & $S D$ & Rank \\
\hline 1. The education offered to students at our school is of high quality. & 3.75 & 0.864 & 2 & 3.72 & 0.826 & 4 \\
\hline 2. The school is doing a good job teaching mathematics and sciences. & 3.83 & 0.825 & 1 & 3.81 & 0.784 & 2 \\
\hline 3. The school is doing a good job teaching other subjects. & 3.66 & 0.856 & 3 & 3.70 & 0.864 & 5 \\
\hline 4. The teaching strategies used at this school are innovative. & 3.49 & 0.993 & 5 & 3.47 & 0.992 & 9 \\
\hline 5. Teachers are efficient (well-prepared and highly-qualified). & 3.62 & 0.910 & 4 & 3.74 & 0.889 & 3 \\
\hline $\begin{array}{l}\text { 6. The school is preparing students to deal with issues and the } \\
\text { problems they will face in the future. }\end{array}$ & 3.24 & 1.036 & 8 & 3.39 & 0.942 & 10 \\
\hline $\begin{array}{l}\text { 7. Teachers use a variety of teaching strategies and learning activities } \\
\text { to help students learn. }\end{array}$ & 3.25 & 1.009 & 7 & 3.53 & 0.965 & 7 \\
\hline $\begin{array}{l}\text { 8. Teachers use the advanced technology to deliver knowledge for } \\
\text { students, such as computers, smart boards, and projectors. }\end{array}$ & 2.98 & 1.194 & 9 & 3.61 & 1.157 & 6 \\
\hline 9. The children have been enabled to learn English language. & 2.89 & 1.195 & 10 & 3.48 & 1.058 & 8 \\
\hline $\begin{array}{l}\text { 10. The school provides extra curricula, such as English and computer } \\
\text { sciences. }\end{array}$ & 3.27 & 1.255 & 6 & 3.92 & 1.007 & 1 \\
\hline
\end{tabular}

Table 5 demonstrates the most important quality of instruction items for the participants, who sent their children to public school, i.e., the mean score of the majority of items came above 3.48. The highest placed, in terms of dimension order, was Item 2, "The school is doing a good job teaching mathematics and sciences," which was rated at 3.83 with a standard deviation of 0.825 . Very close to this, ranked second by mean score, 
was Item 1, "The education offered to students at our school is of high quality," which was rated at 3.75 with a standard deviation of 0.864. In the third place, respectively, came Item 3, "The school is doing a good job teaching other subjects," which was rated at 3.66 with a standard deviation of 0.856. Less important items included Item 9, "The children have been enabled to learn English language," which was rated at 2.89 with a standard deviation of 1.195 . Very close to this, ranked penultimate by mean score was Item 8 , "The teacher used advanced technology to deliver knowledge for students, such as computers, smart boards, and projectors," which was rated at 2.98 with a standard deviation of 1.194. Finally, Item 10, "The school provides additional subjects, such as English and computer sciences," was rated at 3.27 with a standard deviation of 1.255.

Regarding parents who sent their children to private school, the most important factor in their perception in terms of quality of instruction was Item 10, "The school provides additional subjects, such as English and computer sciences," which was rated at 3.92 with a standard deviation of 1.007. The second most important item was Item 2, "The school is doing good job teaching mathematics and sciences," which was rated at 3.81 with a standard deviation of 0.784 . The third most important item was Item 5, "Teachers are efficient (well-prepared and highly-qualified)," which was rated at 3.74 with a standard deviation of 0.889 . On the other hand, less important items were Item 6, "The school is preparing students to deal with issues and the problems they will face in the future," which was rated at 3.39 with a standard deviation of 0.942 . This is followed by Item 9, "The children have been enabled to learn the English language," which was rated at 3.48 with a standard deviation of 1.058. The last item was Item 7, "Teachers use the variety of teaching strategies and learning activities to help students learn," which was rated at 3.53 with a standard deviation of 0.965 .

\section{Student-Teacher Relationships}

This section records participants' answers to the sub-question: Does the student-teacher relationships factor affect parents' decisions to enter their children into public or private school in Riyadh, KSA?

The third academic related dimension (student-teacher relationships) revealed a higher level of agreement between participants (see Table 6).

Table 6

Frequency, Percent, Mean, and Standard Deviation for Each Item Related to Student-Teacher Relationships

\begin{tabular}{|c|c|c|c|c|c|c|}
\hline \multirow{2}{*}{ Factor } & \multicolumn{3}{|c|}{ Public } & \multicolumn{3}{|c|}{ Private } \\
\hline & $M$ & $S D$ & Rank & $M$ & $S D$ & Rank \\
\hline 1. The relationship between the teachers and students is very good. & 3.63 & 0.968 & 3 & 3.64 & 0.922 & 3 \\
\hline 2. Teachers at our school treated my child fairly. & 3.93 & 1.008 & 1 & 3.89 & 0.882 & 2 \\
\hline 3. Teachers are friendly and sincere with students. & 3.73 & 1.013 & 2 & 3.90 & 0.825 & 1 \\
\hline
\end{tabular}

Table 6 illustrates the most important perceived factors for participants who chose public school for their children. The highest ranked item was Item 2, "Teachers at our school treated my child fairly," which was rated at 3.93 with a standard deviation of 1.008 . Second place was held by Item 3, "Teachers are friendly and sincere with students," which was rated at 3.73 with a standard deviation of 1.013. Finally, Item 1, "The relationship between the teachers and students is very good," was rated at 3.63 with a standard deviation of 0.968 .

For parents who sent their children to private school, Item 3 was ranked as most important, with a mean response of 3.90 and a standard deviation of 0.825 . The second most important item was Item 2, which was rated at 3.89 with a standard deviation of 0.882 . The last item was Item 1, which was rated at 3.64 with a standard deviation of 0.922 . 
In summary, the three dimensions - class size, quality of instruction, and student-teacher relationships - have been identified as the most important academic related issues in respect to school choice. This is because parents give high priority, even to the extent of either considering or actually sending their children to a more distant school, in order to be assured that their children would be taught by qualified committed teachers.

More specifically, overall parental perceptions of the preferred school in terms of these academic factor aspect included:

1. The school is doing a good job teaching mathematics and sciences;

2. The education offered to students at our school is of high quality;

3. Teachers are friendly and sincere with students;

4. Teachers at our school treated my child fairly.

The most important factors that had an impact upon parents' choice of private school, however, were:

1. The school provides additional subjects, such as English and computer sciences;

2. The school is doing a good job teaching mathematics and sciences;

3. Class size at our school is appropriate for effective learning;

4. Teachers at our school treated my child fairly;

5. Teachers are friendly and sincere with students.

\section{Inferential Statistics}

In addition to the above analysis, an independent $t$-test was conducted to explore if there are statistically significant differences between the two groups of parents in terms of the three factors and school choice decisions. Only class size, quality of instruction, and student-teacher relationships will be discussed.

Class size factor. Table 7 shows the independent samples $t$-test in respect to the class size factor. The results revealed that there is a significant difference between parents who chose private schools and parents who chose public schools $\left(t_{(355.7)}=7.49 ; p=0.000[p<0.001]\right)$. The private school group showed a higher score of 4.04 compared to the public school category who had a mean score of 3.27. Parental views about the importance of class size, therefore, significantly affect the type of school they choose.

Table 7

Results of an Independent T-Test Regarding the Difference Between Private and Public School Choice in Respect to the Class Size Factor

\begin{tabular}{|c|c|c|c|c|c|c|c|c|c|}
\hline School type & \multicolumn{2}{|l|}{$N$} & \multicolumn{3}{|c|}{$M$} & \multicolumn{2}{|l|}{$S D$} & \multicolumn{2}{|c|}{ Std. error mean } \\
\hline Private & \multicolumn{2}{|c|}{192} & \multicolumn{3}{|c|}{4.0469} & \multicolumn{2}{|l|}{0.85179} & \multicolumn{2}{|l|}{0.06147} \\
\hline Public & \multicolumn{2}{|c|}{194} & \multicolumn{3}{|c|}{3.2758} & \multicolumn{2}{|l|}{1.15057} & \multicolumn{2}{|l|}{0.08261} \\
\hline \multirow{3}{*}{ Class size } & \multicolumn{3}{|c|}{$\begin{array}{c}\text { Levene's test for } \\
\text { equality of variances }\end{array}$} & \multicolumn{4}{|c|}{$T$-test for equality of means } & & \\
\hline & \multirow[t]{2}{*}{$F$} & \multirow[t]{2}{*}{ Sig. } & \multirow[t]{2}{*}{$T$} & \multirow[t]{2}{*}{$D f$} & \multirow{2}{*}{$\begin{array}{l}\text { Sig. } \\
\text { (2-tailed) }\end{array}$} & \multirow{2}{*}{$\begin{array}{l}\text { Mean } \\
\text { difference }\end{array}$} & \multirow{2}{*}{$\begin{array}{l}\text { Std. error } \\
\text { difference }\end{array}$} & \multicolumn{2}{|c|}{$\begin{array}{l}95 \% \text { confidence interval } \\
\text { of the difference }\end{array}$} \\
\hline & & & & & & & & Lower & Upper \\
\hline $\begin{array}{l}\text { Equal variances } \\
\text { assumed }\end{array}$ & 28.219 & 0.000 & 7.477 & 384 & 0.000 & 0.77110 & 0.10313 & 0.56834 & 0.97386 \\
\hline $\begin{array}{l}\text { Equal variances } \\
\text { not assumed }\end{array}$ & - & - & 7.489 & 355.716 & 0.000 & 0.77110 & 0.10297 & 0.56860 & 0.97361 \\
\hline
\end{tabular}


All of the participants, who chose a private school did so because of the small numbers in the classes. This is supported by Parent $2.5^{1}$ who mentioned that:

I have preferred a private school because studies have proved that small classes offer and grant learners opportunities to interact more with teachers and friends, to ask questions, discuss the use of technology to convey knowledge and things. Also, small classes assist the teacher to control the class better, unlike large classes where teachers cannot make as much difference between active willing learner student and lazy students. Therefore, the private school tries to provide small class. So that is why I think it is to be preferred.

Further, Parent 2.2 agreed that:

I selected the private school for my son, because the number of pupils in the classroom was between 12 and 18, which meant my son will have a chance to interact with teachers and with his friends in the classrooms and to ask any question or discuss any matter with teachers. Therefore, the private schools in Riyadh City focused on the reduction of the number of pupils in each class, because parents take their children out of the public schools due to the large numbers of pupils in public school classes. Moreover, it helps the teachers to manage the class better in terms of teaching and learning as well.

Quality of instruction factor. Table 8 shows the independent samples $t$-test results for the quality of instruction factor. The results revealed that there is a significant difference between parents who chose private schools and parents who chose public schools $\left(t_{(384)}=3.91 ; p=0.000[p<0.001]\right)$. The private school group showed a higher mean score of 3.65, compared to the public school category who had a mean score of 3.39. This suggests that the relative emphasis that parents place on the quality of instruction in a school has a significant effect on their school choice.

Table 8

Results of an Independent T-Test Regarding the Difference Between Private and Public School Choice in Respect to the Quality of Instruction Factor

\begin{tabular}{|c|c|c|c|c|c|c|c|c|c|}
\hline School type & \multicolumn{2}{|l|}{$N$} & \multicolumn{2}{|c|}{$M$} & \multicolumn{3}{|c|}{$S D$} & \multicolumn{2}{|c|}{ Std. error mean } \\
\hline Private & \multicolumn{2}{|c|}{192} & \multicolumn{2}{|c|}{3.6557} & & \multicolumn{2}{|l|}{0.64132} & \multicolumn{2}{|l|}{0.04628} \\
\hline Public & \multicolumn{2}{|c|}{194} & \multicolumn{2}{|c|}{3.3877} & & \multicolumn{2}{|l|}{0.70211} & \multicolumn{2}{|l|}{0.05041} \\
\hline \multirow{3}{*}{$\begin{array}{l}\text { Quality of } \\
\text { instruction factor }\end{array}$} & \multicolumn{3}{|c|}{$\begin{array}{c}\text { Levene's test for } \\
\text { equality of variances }\end{array}$} & \multicolumn{4}{|c|}{$T$-test for equality of means } & & \\
\hline & \multirow[t]{2}{*}{$F$} & \multirow[t]{2}{*}{ Sig. } & \multirow[t]{2}{*}{$T$} & \multirow[t]{2}{*}{$D f$} & \multirow{2}{*}{$\begin{array}{l}\text { Sig. } \\
\text { (2-tailed) }\end{array}$} & \multirow{2}{*}{$\begin{array}{l}\text { Mean } \\
\text { difference }\end{array}$} & \multirow{2}{*}{$\begin{array}{l}\text { Std. error } \\
\text { difference }\end{array}$} & \multicolumn{2}{|c|}{$\begin{array}{c}95 \% \text { confidence interval } \\
\text { of the difference }\end{array}$} \\
\hline & & & & & & & & Lower & Upper \\
\hline $\begin{array}{l}\text { Equal variances } \\
\text { assumed }\end{array}$ & 2.525 & 0.113 & 3.913 & 384 & 0.000 & 0.26793 & 0.06847 & 0.13331 & 0.40254 \\
\hline $\begin{array}{l}\text { Equal variances } \\
\text { not assumed }\end{array}$ & - & - & 3.915 & 381.560 & 0.000 & 0.26793 & 0.06843 & 0.13337 & 0.40248 \\
\hline
\end{tabular}

From these results and literature review, there is a close correlation between quality of instruction and student-teacher relationships.

Student-teacher relationships factor. Table 9 illustrates the independent samples $t$-test results in respect to the relationship between teachers and students. The results showed that there were no significant differences between parents who chose private schools and parents who chose public schools $\left(t_{(374.6)}=0.530 ; p=0.596\right.$ $[p>0.05])$. The private school group showed a score of 3.80, compared to the public school category who had

\footnotetext{
${ }^{1}$ Explanation of the code: 2 stands for private school parents, while 5 stands for the number of parents.
} 
a score of 3.76. The parents' views on the importance of a good relationship between teachers and students, therefore, have no significant effect on their school choice decisions.

Table 9

Results of an Independent T-Test Regarding the Difference Between Private and Public School Choice in Respect to the Relationship Between Teachers and Students Factor

\begin{tabular}{|c|c|c|c|c|c|c|c|c|c|}
\hline School type & \multicolumn{2}{|l|}{$N$} & \multicolumn{3}{|c|}{$M$} & \multicolumn{2}{|l|}{$S D$} & \multicolumn{2}{|c|}{ Std. error mean } \\
\hline Private & \multicolumn{2}{|l|}{192} & & \multicolumn{2}{|l|}{3.8090} & \multicolumn{2}{|l|}{0.72155} & \multicolumn{2}{|l|}{0.05207} \\
\hline Public & \multicolumn{2}{|l|}{194} & & \multicolumn{2}{|l|}{3.7663} & \multicolumn{2}{|l|}{0.85529} & \multicolumn{2}{|l|}{0.06141} \\
\hline \multirow{3}{*}{$\begin{array}{l}\text { Relationship } \\
\text { between teachers } \\
\text { and students }\end{array}$} & \multicolumn{4}{|c|}{$\begin{array}{c}\text { Levene's test for } \\
\text { equality of variances }\end{array}$} & \multicolumn{3}{|c|}{$T$-test for equality of means } & & \\
\hline & \multirow[t]{2}{*}{$F$} & \multirow[t]{2}{*}{ Sig. } & \multirow[t]{2}{*}{$T$} & \multirow[t]{2}{*}{$D f$} & \multirow{2}{*}{$\begin{array}{l}\text { Sig. } \\
\text { (2-tailed) }\end{array}$} & \multirow{2}{*}{$\begin{array}{l}\text { Mean } \\
\text { difference }\end{array}$} & \multirow{2}{*}{$\begin{array}{l}\text { Std. error } \\
\text { difference }\end{array}$} & \multicolumn{2}{|c|}{$\begin{array}{c}95 \% \text { confidence interva } \\
\text { of the difference }\end{array}$} \\
\hline & & & & & & & & Lower & Upper \\
\hline $\begin{array}{l}\text { Equal variances } \\
\text { assumed }\end{array}$ & 4.446 & 0.036 & 0.530 & 384 & 0.596 & 0.04270 & 0.08058 & -0.11574 & 0.20115 \\
\hline $\begin{array}{l}\text { Equal variances } \\
\text { not assumed }\end{array}$ & - & - & 0.530 & 374.62 & 0.596 & 0.04270 & 0.08051 & -0.11561 & 0.20102 \\
\hline
\end{tabular}

Although the relationship between teachers and students is seen as important in the choice of private school as three out of the five parents considered that despite this positive aspect, private schools suffer from some teachers, who cannot deal with students fairly nor effectively address bad behaviour among students. For example, in the semi-structured interview, Parent 2.4 mentioned that:

The reinforcing of positive effects and values on students depends on the relationship of teachers with students. Some teachers do not have enough experience to deal well with my son or have an effect on him to enhance religious values. Some teachers are very careless and have no caring or give consideration about this issue. This means private schools do not have a clear mechanism for teachers to rely upon to enable them to address and cure improper behaviour, by enhancing the relationship between the teachers and students.

Whilst Parent 2.5 admitted that:

I did not note how or if the teacher contributes to the positive behaviour, because this function falls on the family, not the school, therefore, I do not put the blame on the teachers, because I believe the parents are responsible to unaccepted behaviour in school and they must enhance the good behaviour in their children.

Regarding the link between class size and quality of instruction, the independent samples $t$-test showed that the mean of the class size factor in the responses of parents who had chosen public school was 3.27, while the mean among private school parents was 4.046. This result illustrates that that there were significant differences between public schools and private schools in the impact of class size factor, at $t_{(355.7)}=7.49$; $p=0.000(p<0.001)$.

These results, which are detailed in full in Table 7, demonstrate that for most participants whose preference was for private school, this was due to the class size, as private school parents strongly held the view that a smaller class allowed more effective pupil learning. Therefore, small numbers in a classroom were ideal for this to happen.

This result was confirmed by the Logistic Regression results, which demonstrates that the most significant predictor of school choice was class size; hence, participants who score highly on class size are more likely to choose private schools. This is in agreement with the findings of previous studies conducted across the world, 
which have found that small class size is a significant factor influencing parents to choose private school: cf. for example, U.S. parents' tendency to choose private school on account of class size (Taylor, 1996; Bosetti, 2004; Denessen et al., 2005; Bukari \& Randall, 2009; Charles, 2011). Furthermore, among the Gulf countries, a study found that Kuwaiti parents choose private school due to concern about class size (Al-Mutawa \& Al-Watfa, 2007).

In addition to the above, statistics confirmed that, in general, private schools have smaller class sizes than public schools, besides being much more selective of the academic ability of the pupils whom they enrol, whilst claiming to enhance the potential of all of its pupils (Tennessee Department of Education, 2009; Ministry of Education, 2013).

Nonetheless, these findings are not consistent with Edmondson and Mulder (1924), Bourke (1986), Hanushek (1986), Nye et al. (2002), and Pascarella and Terenzini (1991), who found that there was no significant impact of class size on pupils' performance. Whilst, Johnson (2010) found that there were no significant differences between small or large class sizes when compared with one another.

In light of the above discussion, it was found that the majority of KSA parents withdrew their children from public schools to send them to private schools based simply on their perception that the class size was much more effective and offered numerous advantages when considered with the quality of instruction. As a result of this study, class size is a highly significant issue that is taken into consideration when KSA parents make their choice of school.

These results support the student-teacher relationship findings of previous studies, such as LaParo, Pianta, and Stuhlman (2004) and Cassidy, Hestenes, Hansen, Hedge, Shim, and Hestenes (2005), each of which argued that a small class size allowed teachers to interact more effectively with pupils. This effective interaction in KSA was, in turn, perceived to develop and enhance pupils' performance. Al-Ansari (2004) confirmed that class size significantly influenced student-teacher relationships as this enabled teachers to apply new, innovative methods of teaching that in turn stimulated pupils to utilize creative thinking skills.

Furthermore, this study corresponds with Kharman (2005), who stated that a small class size is very important in order for quality of instruction, i.e., teaching and learning to be delivered in such a way as to be interesting and enjoyable for the learners. It also allows teachers to have sufficient time to become familiar with pupils in terms of solving problems and developing positive thinking skills and work ethics. Further, LaParo et al. (2004) and Cassidy et al. (2005) advocated that small class sizes allowed quality of instruction and student-teacher relationships to interact with pupils much more effectively and frequently, resulting in a more positive development of pupils' performance.

\section{Conclusion}

In summary, therefore, based on the findings of this study, the following conclusions were drawn by the researcher.

In this study, the majority of the participants highly prefer the private schools due the academic factors, which means that they had extensive experience of a variety of education systems. Consequently, this result can be attributed to these participants being likely to have had personal experiences to draw upon from their own education and therefore having an appreciation and understanding of the importance of effective teaching and learning outcomes, particularly those that incorporate modern technologies. Such positive experiences may, therefore, influence their wish for their children to have the opportunity to gain similar experiences. 
Furthermore, this study revealed that private school is perceived by parents as being superior to public school in terms of aspects such as class size, quality of instruction, and student-teacher relationships.

Data cited in the results would make a considerable contribution towards a clear, in-depth understanding of the current educational provision in KSA and the ways in which it can be enhanced to meet the challenges of the 21 st century global economy.

\section{Recommendations}

This study coincided and is very much compatible with the KSA Ministry of Education's 10 billion Saudi Riyals funding intentions to fulfil its aim to provide effective 21 st century challenging educational teaching and learning processes by developing its existing education provision and to identify ineffective and effective teaching/learning outcomes utilizing modern technologies.

To support and contribute towards the Ministry of Education's enhancement of the educational opportunities currently being offered, it is recommended that:

1. Class size is a top priority for parents based upon their perception that the smaller the number of pupils per teacher, the more individual tuition could be offered. A small class size enhances learning outcomes of pupils, making schools more attractive to parents.

2. Small class sizes offer opportunities for quality of instruction to develop a wide variety of practices, teaching strategies, and student-teacher relationships to address individual pupils' needs and potential, taking into account the different abilities of their individual pupils.

3. More public schools should be built to meet the current overcrowding caused by the recent population explosion in KSA. More teachers should be employed so that the student-teacher ratio can be reduced, making public schools more attractive to parents.

\section{Further Research}

This study was applied only in Riyadh. It would be beneficial to carry out this study, or a similar one, in other KSA cities to obtain comparisons of findings and to highlight specific needs or issues related to other KSA cities, to enhance the overall effectiveness of the national education system in KSA.

This study was conducted with males only, so, a similar type of study should be carried out, with females to have informative comparison of results with a view to enhancing the overall effectiveness of the national education system in KSA.

This study focused on parents to assess KSA primary private and public school to evaluate aspects of education in both systems from parents' perspectives to assist overall effectiveness of the KSA national education system and further study should focus on primary school.

\section{References}

Al-Ansari, A. (2004). The reasons behind enrolment of children in private schools and views of parents about the private schools. Education Studies, 23, 2-17. (In Arabic)

Alassaf, A. (2010). Introduction to research in behavioural sciences. Riyadh: Dar Alzharia. (In Arabic)

Albiker, F. (1994). The factors that influence the parents' choice of school. Education Studies, 15-40. (In Arabic)

Al-Ghamdi, S., \& Asiri, M. (1992). The role of private schools in education compared to the public schools in Taif City. Journal of Educational, 25, 219-271. (In Arabic)

Al-Jaji, A. (2002). The perspectives of parents towered private schools in Saudi Arabia. Journal of Immam Mohammed bin Saudi University, 37, 563-597. (In Arabic) 
Al-Mutawa, F., \& Al-Watfa, A. (2007). Private Kuwaiti schools in the perspective of parents. Arabian Gulf Message Journal, 109, $1-90$

Al-Shimri, A. (1999). The factors influence the parents to choice the private school (Unpublished master's thesis, University of King Saud, Riyadh). (In Arabic)

Anderson, K. M., \& Resnick, M. A. (1997). Careful comparisons: Public and private schools in America. Alexandria: National School Board Association.

Angeloni, M. (2012). What are parents searching for when faced with school choice options? (Unpublished doctoral dissertation, University of Capella).

Bauch, P. A., \& Goldring, E. B. (1995). Parent involvement and school responsiveness: Facilitating the home-school connection in schools of choice. Educational Evaluation and Policy Analysis, 17, 1-21.

Bosetti, L. (2004). Determinants of school choice: Understanding how parents choose elementary schools in Alberta. Journal of Education Policy, 19(4), 387-405.

Bourke, S. (1986). How smaller is better: Some relationships between class size, teaching practices, and student achievement. American Educational Research Journal, 23(4), 558-571.

Bukari, P., \& Randall, E. V. (2009). Exit and entry: Why parents in Utah left public schools and chose private schools. Journal of School Choice, 1558-2159.

Burgess, S., McConnell, B., Propper, C., \& Wilson, D. (2007). The impact of school choice on sorting by ability and socio-economic factors in English secondary education. In L. Woessmann, \& P. Peterson (Eds.), Schools and the equal opportunity problem. Cambridge, M.A.: MIT Press.

Burleson, B. R., \& Samter, W. (1990). Effects of cognitive complexity on the perceived importance of communication skills in friends. Communication Research, 17, 165-182.

Buttrum, H. R. (1994). Factors influencing parental decisions to enroll students in selected private schools in Arkansas during the past three years (Ed.D. dissertation, University of Arkansas).

Cassidy, D. J., Hestenes, L. L., Hansen, J. K., Hedge, A., Shim, J., \& Hestenes, S. (2005). Revisiting the two faces of child care quality: Structure and process. Early Education and Development, 16(4), 505-520.

Charles, G. W. (2011). Parental perceptions of school quality in public and private schools (Ed.D. dissertation, Northcentral University).

Cohen, L., Manion, L., Morrison, K., \& Bell, R. (2011). Research methods in education (7th ed.). London, U.K.: Routledge.

Coleman, J., Hoffer, T., \& Kilgore, S. (1982). High school achievement: Public, catholic, and private school compared. New York, N.Y.: Basic Books.

Collins, A., \& Snell, M. C. (2000). Parental preferences and choice of school. Applied Economics, 32(7), 803-813.

Denessena, E., Driessenaa, G., \& Sleegers, P. (2005). Segregation by choice? A study of group-specific reasons for school choice. Journal of Education Policy, 20, 347-368.

Edmondson, J. B., \& Mulder, F. J. (1924). Size of class as a factor in university instruction. Journal of Educational Research, 9 , $1-12$.

Finn, J. D., \& Achilles, C. M. (1999). Tennessee's class size study: Findings, implications, misconceptions. Educational Evaluation and Policy Analysis, 21(2), 97-109.

Gibbs, G., Lucas, L., \& Simonite, V. (1996). Class size and student performance: 1984-94. Studies in Higher Education, 21(3), 261-273.

Gilbert, G. N. (2008). Researching social life (3rd ed.). Los Angeles, C.A.: Sage.

Good, T. L., \& Brophy, J. E. (1995). Contemporary educational psychology (5th ed.). White Plains, N.Y.: Longman.

Hanushek, E. A. (1986). The economics of schooling: Production and efficiency in public schools. Journal of Economic Literature, 24, 1141-1177.

Hargreaves, A. (1994). Changing teachers, changing times: Teacher's work and culture in the postmodern age. New York, N.Y.: Teachers College Press.

Johnson, Y. (2010). Class size and student performance at a public research university: A cross-classified model. Research in Higher Education, 51, 701-723.

Kharman, N. M. (2005). Educational developments in Jordan: A comparison of private and public schools (Doctoral dissertation, University of Reading).

Kitzinger J. (1995). Introducing focus groups. British Medical Journal, 311, 299-302. 
Knoell, M. (2012). The role of the students-teacher relationship in the lives of fifth graders: A mixed methods analysis. (Unpublished doctoral dissertation, University of Nebraska, Nebraska).

Krueger, A. B. (1999). Experimental estimates of education production functions. Quarterly Journal of Economics, 114, 497-532.

Kyriacou, C. (2007). Essential teaching skills. Cheltenham, U.K.: Nelson Thornes.

LaParo, K. M., Pianta, R. C., \& Stuhlman, M. (2004). The classroom assessment scoring system: Findings from the prekindergarten year. Elementary School Journal, 104(5), 409-426.

Lee, S. J. (2007). The relations between the student-teacher trust relationship and school success in the case of Korean middle schools. Educational Studies, 33(2), 209-216.

Marlow, M. L. (2010). The influence of private school enrollment on public school performance. Applied Economics, 42, 11-22.

Ministry of Education. (2009). About the Ministry of Education. Retrieved August 20, 2012, from http://www.moe.gov.sa/open share/englishcon/Introducti/history.htm_cvt.html

Ministry of Education. (2013). Department of Statistics. Retrieved May 20, 2014, from https://www.moe.gov.sa/Arabic/ PublicAgenciesAndDepartments/EducationalInformationCenter/Pages/th-m.asp

National Center for Education Statistics (NCES). (2003). Private schools: A brief portrait. Retrieved June 23, 2013, from http://nces.ed.gov/pubs2002/2002013.pdf

Nye, B., Hedges, L. V., \& Konstantopoulos, S. (2000). Do the disadvantaged benefit from the small classes? Evidence from the Tennessee class size experiment. American Journal of Education, 109, 1-26.

Nye, B., Hedges, L. V., \& Konstantopoulos, S. (2002). Do low achieving students benefit more from small classes? Evidence from the Tennessee class size experiment. Educational Evaluation and Policy Analysis, 24, 201-217.

Pascarella, E., \& Terenzini, P. (1991). How college affects students: Findings and insights from twenty years of research. San Francisco, C.A.: Jossey-Bass.

Pianta, R. C. (1999). Enhancing relationships between children and teachers. Washington, D.C.: American Psychological Association.

Richmond, V. P., \& Gorham, J. (1996). Communication, learning, and affect in instruction (2nd ed.). Edina, M.N.: Burgess.

Sauter, J. H. (1994). An ethnographic study of parental perception of regarding of public school of choice. Wisconsin.

Scheck, C., Kinicki, A., \& Webster, J. (1994). The effect of class size on student performance: Development and assessment of a process model. Journal of Education for Business, 70(2), 104-111.

Shanker, A. (1993). Public vs. private school. National Forum, 73, 14-17.

Taylor, R. J. K. (1996). Variables motivating parents to choose a specific type of private school. Miami, F.L.: Florida International University.

Tennessee Department of Education. (2009). 2008-2009 non-public school listing. Retrieved August 18, 2011, from http://tennessee.gov/education/nonpublic/doc/09-10-nonpublic-sch.xls

Wimmer, R., \& Dominick, J. (2000). Mass media research: An introduction (6th ed.). Belmont, C.A.: Wadsworth.

Wisker, G. (2007). The postgraduate research handbook: Succeed with your MA, MPhil, Ed.D., and PhD. Basingstoke, U.K.: Palgrave Macmillan. 